\title{
Marine biodiversity research in the Ryukyu Islands, Japan: Current status and trends
}

\author{
James Davis Reimer ${ }^{\text {Corresp., }}{ }^{1,2}$ ， Piera Biondi ${ }^{1}$, Yee Wah Lau ${ }^{1}$, Giovanni Diego Masucci ${ }^{1}$, Xuan Hoa Nguyen ${ }^{1}$, \\ Maria E.A. Santos ${ }^{1}$, Hin Boo Wee ${ }^{1}$ \\ ${ }^{1}$ Graduate School of Engineering and Science, University of the Ryukyus, Nishihara, Okinawa, Japan \\ 2 Tropical Biosphere Research Center, University of the Ryukyus, Nishihara, Okinawa, Japan \\ Corresponding Author: James Davis Reimer \\ Email address: jreimer@sci.u-ryukyu.ac.jp
}

Marine biodiversity and derived ecosystem services are critical to the healthy functioning of marine ecosystems, and to human economic and societal well-being. Thus, an understanding of marine biodiversity in different ecosystems is necessary for their conservation and management. Coral reefs in particular are noted for their high levels of biodiversity, and among the world's coral reefs, the subtropical Ryukyu Archipelago (RYS; also known as the Nansei Islands) in Japan has been shown to harbor very high levels of marine biodiversity. This study provides an overview of the state of marine biodiversity research in the RYS. First, we examined the amount of English language scientific literature in the Web of Science (WoS; 1995-2017) on six selected representative taxa spanning protists to vertebrates across six geographic sub-regions in the RYS. Our results show clear taxonomic and sub-region bias, with research on Pisces, Cnidaria, and Crustacea to be much more common than on Dinoflagellata, Echinodermata, and Mollusca. Such research was more commonly conducted in sub-regions with larger human populations (Okinawa, Yaeyama). Additional analyses with the Ocean Biogeographic Information System (OBIS) records show that within sub-regions, records are concentrated in areas directly around marine research stations and institutes (if present), further showing geographical bias within sub-regions. While not surprising, the results indicate a need to address 'understudied' taxa in 'understudied sub-regions' (Tokara, Miyako, Yakutane, Amami Oshima), particularly sub-regions away from marine research stations. Second, we compared the numbers of English language scientific papers on eight ecological topics for the RYS with numbers from selected major coral reef regions of the world; the Caribbean (CAB), Great Barrier Reef (GBR), and the Red Sea (RES). As expected, the numbers for all topics in the RYS were well below numbers from all other regions, yet within this disparity, research in the RYS on 'marine protected areas' and 'herbivory' was an order of magnitude lower than numbers in other regions. Additionally, while manuscript 
numbers on the RYS have increased from 1995 to 2016, the rate of increase (4.0 times) was seen to be lower than those in the CAB, RES, and GBR (4.6 to 8.4 times). Coral reefs in the RYS feature high levels of both endemism and anthropogenic threats, and subsequently they contain a concentration of some of the world's most critically endangered marine species. To protect these threatened species and coral reef ecosystems, more data are needed to fill the research gaps identified in this study. 
1 Marine biodiversity research in the Ryukyu Islands, Japan: Current status

\section{2 and trends}

3

4 James Davis Reimer ${ }^{1,2 *}$, Piera Biondi ${ }^{1}$, Yee Wah Lau ${ }^{1}$, Giovanni Diego Masucci ${ }^{1}$, Xuan Hoa

5 Nguyen ${ }^{1}$, Maria E. A. Santos ${ }^{1}$, Hin Boo Wee ${ }^{1}$

6

7 All authors contributed equally to this publication

$8{ }^{1}$ Graduate School of Science and Engineering, University of the Ryukyus, 1 Senbaru, Nishihara,

9 Okinawa 903-0213, Japan

$10{ }^{2}$ Tropical Biosphere Research Center, University of the Ryukyus, 1 Senbaru, Nishihara, Okinawa

11 903-0213, Japan

$12 *$ corresponding author: jreimer@sci.u-ryukyu.ac.jp 


\section{Abstract}

16 Marine biodiversity and derived ecosystem services are critical to the healthy functioning of

17 marine ecosystems, and to human economic and societal well-being. Thus, an understanding of

18 marine biodiversity in different ecosystems is necessary for their conservation and management.

19 Coral reefs in particular are noted for their high levels of biodiversity, and among the world's

20 coral reefs, the subtropical Ryukyu Archipelago (RYS; also known as the Nansei Islands) in

21 Japan has been shown to harbor very high levels of marine biodiversity. This study provides an

22 overview of the state of marine biodiversity research in the RYS. First, we examined the amount

23 of English language scientific literature in the Web of Science (WoS; 1995-2017) on six selected

24 representative taxa spanning protists to vertebrates across six geographic sub-regions in the RYS.

25 Our results show clear taxonomic and sub-region bias, with research on Pisces, Cnidaria, and

26 Crustacea to be much more common than on Dinoflagellata, Echinodermata, and Mollusca. Such

27 research was more commonly conducted in sub-regions with larger human populations (Okinawa,

28 Yaeyama). Additional analyses with the Ocean Biogeographic Information System (OBIS)

29 records show that within sub-regions, records are concentrated in areas directly around marine

30 research stations and institutes (if present), further showing geographical bias within sub-regions. 
31 While not surprising, the results indicate a need to address 'understudied' taxa in 'understudied

32 sub-regions' (Tokara, Miyako, Yakutane, Amami Oshima), particularly sub-regions away from

33 marine research stations. Second, we compared the numbers of English language scientific

34 papers on eight ecological topics for the RYS with numbers from selected major coral reef

35 regions of the world; the Caribbean (CAB), Great Barrier Reef (GBR), and the Red Sea (RES).

36 As expected, the numbers for all topics in the RYS were well below numbers from all other

37 regions, yet within this disparity, research in the RYS on 'marine protected areas' and 'herbivory'

38 was an order of magnitude lower than numbers in other regions. Additionally, while manuscript

39 numbers on the RYS have increased from 1995 to 2016, the rate of increase (4.0 times) was seen

40 to be lower than those in the CAB, RES, and GBR (4.6 to 8.4 times). Coral reefs in the RYS

41 feature high levels of both endemism and anthropogenic threats, and subsequently they contain a

42 concentration of some of the world's most critically endangered marine species. To protect these

43 threatened species and coral reef ecosystems, more data are needed to fill the research gaps

44 identified in this study.

46 Introduction 
49 (Costanza et al. 1997; Mace et al. 2012). Moreover, knowledge of biodiversity patterns enables

50 the prediction of possible outcomes from ongoing environmental changes (Bellard et al. 2012)

51 and species extinctions (Chapin et al. 2000; Dunne et al. 2002). Analyses of species diversity

52 and distribution also allow the determination of biodiversity hotspots. For example, the 'Coral

53 Triangle' hotspot, located in central Indo-Pacific waters, is considered to be the coral reef area

54 with the highest numbers of marine species in the world (Hughes et al. 2002; Toonen et al. 2016).

55 Nevertheless, there is still a lack of diversity information for most marine taxa (Appeltans et al.

56 2012; Troudet et al. 2017), and this problem is especially prevalent in understudied localities

57 including many in the Indo-Pacific. Such data gaps lead to incomplete or inaccurate knowledge

58 of biodiversity patterns, limiting our ability to determine appropriate conservation measures for

59 species and ecosystem functions (Cardinale et al. 2012; Costello et al. 2013; Duffy et al. 2017).

61 southernmost region of Japan and border the northern edge of the Coral Triangle, spanning 1200

$62 \mathrm{~km}$ from Yakushima and Tanegashima Islands (Yakutane sub-region) in the north, across the 
63 Tokara, Amami, Okinawa, Miyako sub-regions to the Yaeyama Islands in the south (Fig. 1, also

64 Nishihira 2004; Fujita et al. 2015). The RYS includes islands of different geological formation,

65 ages, and sizes (Kizaki 1986; Table 1). The waters of the RYS are all influenced by the warm

66 Kuroshio Current that flows northwards along the west side of the island chain (Andres et al.

67 2008). Thus, the RYS are a marine region of exceptionally high diversity and endemism (Hughes

68 et al. 2002; Cowman et al. 2017). Moreover, southern Japan and Taiwan rank first in global

69 marine conservation priority when considering high levels of multi-taxon endemism, their high

70 risk of biodiversity loss due to overexploitation and coastal development, and thus need rapid

71 conservation action (Roberts et al. 2002). More than one decade after this initial work, and

72 despite some conservation successes (e.g. Okubo and Onuma 2015; establishment of Keramas

73 National Park in 2016), the RYS are still threatened by rapidly increasing tourism pressure (Dal

74 Kee 2015; Hirano and Kakutani 2015; Tada 2015; Toyoshima and Nadaoka 2015; Okinawa

75 Prefectural Government 2016) and continuous ongoing coastal developmental (Veron 1992; Fujii

76 et al. 2009; Reimer et al. 2015). In fact, numbers of tourists visiting Okinawa exceeded those of

77 Hawai'i for the first time in 2017 (total number 9,579,900; Ryukyu Shimpo 2018; also FY2017

78 data on Okinawa Prefecture homepage http://www.pref.okinawa.jp/site/bunka- 
sports/kankoseisaku/h28nendo.html).

Although the RYS contain high levels marine species diversity, until now there has

81 been no marine biodiversity overview that covers the archipelago in detail (but see Fujikura et al.

82 (2010)'s general overview of marine biodiversity of Japan with a focus on Sagami Bay). Here,

83 we conduct an extensive English language literature data-mining review to provide information

84 and conduct a gap analysis on the status of marine biodiversity research within the RYS, with

85 specific information on six sub-regions within the RYS for six important and representative

86 marine taxa (Pisces, Crustacea, Echinodermata, Cnidaria, Porifera, Dinoflagellata). Furthermore,

87 we review and compare data of ecological studies in the RYS to those of other major reef regions

88 (Caribbean, Great Barrier Reef, Red Sea). Finally, we discuss and highlight the trends of

89 biodiversity related research in the RYS, emphasizing the need for continued research as the data

90 gaps hamper our understanding of marine biodiversity and conservation efforts in this important

91 coral reef region.

\section{Materials and Methods}

\section{The Ryukyu Islands (RYS)}

We divided the RYS into six sub-regions based on geographical, historical, and 
95 administrative information (Table 1); the sub-regions generally follow those in Coral Reefs of

96 Japan (Nishihira 2004) and as used by various levels of Japanese government. The six sub-

97 regions (south to north) are the island groups of Yaeyama, Miyako, Okinawa, Amami Oshima,

98 Tokara, and Yakutane. The first three sub-regions are within Okinawa Prefecture, while the last

99 three are within Kagoshima Prefecture, and are as follows:

100 a. Yaeyama Islands: the southernmost group of islands in the RYS, this group experiences the

101 most tropical conditions, has the most well-developed coral reefs (Nishihira 2004), including the

102 Sekisei Lagoon, Japan's largest reef system, and is generally thought to have the highest

103 biodiversity within the entire archipelago (Nishihira and Veron 1995; Roberts et al. 2002; Table

104 1). This sub-region includes the major islands of Ishigaki and Iriomote as well as several smaller

105 islands.

106 b. Miyako Islands: includes the large island of Miyako as well as several surrounding smaller

107 islands. This sub-region is notable for having a coral reef system with extensive cave systems

108 and endemic species (e.g. Shimomura et al. 2012).

109 c. Okinawa Main Island and region: this sub-region is dominated by Okinawa Main Island, the

110 largest and by far the most populous island in the RYS (Table 1). In addition, the island is 
111 surrounded by numerous smaller islands notable for their relatively pristine condition and

112 protection within two national parks.

113 d. Amami Oshima Island and region: Amami Oshima is the second largest island in size and

114 population in the RYS, but this region also includes other major islands such as Yoron,

115 Okinoerabu, and Tokunoshima, as well as many smaller island groups. Notable for endemic

116 terrestrial species, the marine life of this subregion is thought to be understudied when compared

117 with regions further south (e.g. Fujii 2016; Nakae et al. 2018). The southernmost portion of

118 Kagoshima Prefecture, this area was historically sometimes included within the former Ryukyu

119 Kingdom (current Okinawa Prefecture).

120 e. Tokara Islands: the smallest and least populated sub-region within the RYS, this group is often

121 considered part of the Yakutane Islands, but differs in several important ways, as it has more

122 developed coral reefs than areas further north in the Yakutane sub-region and south around

123 Amami Oshima (Nakai and Nojima 2004), and is heavily influenced by the Kuroshio Current.

124 This sub-region consists of 12 small islands stretched across $160 \mathrm{~km}$, with six islands having

125 well-developed coral reefs (Nakai and Nojima 2004). As the least developed sub-region, this

126 area, unlike all other sub-regions, is not easily reachable by major air transport systems, and is 
127 considered the least well-studied area in the RYS.

128 f. Yakutane Islands (also known as the Osumi Islands): consisting of the two major islands of

129 Yakushima and Tanegashima along with neighboring smaller islands, the Kuroshio takes a sharp

130 turn to the east south of Yakushima. This sub-region is considered the northern limit of modern

131 coral reef development in the region (Nakai and Nojima 2004) and the northern limit of the

132 subtropical region of Japan.

\section{Web of Science taxa and sub-regions search}

representative marine taxa within the RYS; Pisces, Mollusca, Crustacea, Echinodermata,

136 Cnidaria, and Dinoflagellata, utilizing search strings (Electronic Supplementary Material Table

S1). We determined the sub-region location of each paper of these six taxa within the WoS based

on the title, key words, and abstract information. When the title and abstract only contained

“Okinawa", "Ryukyu", or "Nansei", with no further information, we categorized these papers as

"Ryukyu/Nansei unspecified", as "Okinawa" may refer to the entire Okinawa Prefecture, and

141 "Ryukyu" and "Nansei" may refer to anywhere within the RYS island chain. Additionally, deep-

142 sea publications were not included in our examinations. Publication numbers were compiled for 
143 1995-2017 for each taxon for each sub-region to examine what taxa have been investigated in

144 what sub-region. All information utilized was obtained from within the WoS search tool. The

145 search was conducted in August/September 2017.

\section{Web of Science ecology search and comparison}

147 We searched eight principal topics in ecological studies ("apex predators",

148 "connectivity", "coral bleaching", "coral reproduction", "herbivory", "marine protected areas",

149 "Porifera", "reef-associated bacteria") with in WoS following the search strings utilized by

150 Berumen et al. (2013) in their review on biodiversity work in the Red Sea (see also Electronic

151 Supplementary Material Table S1). Subsequently, we compared the data for four reef regions

152 across the globe. The regions and search strings used to filter the data are the following: RYS

153 (search string was "Ryukyus*” OR "Nansei” OR “Okinawa*”), Caribbean (CAB; search string

154 was “Caribbean”), Great Barrier Reef (GBR; search string was "Great Barrier Reef”), and the

155 Red Sea (RES; search string was "Red Sea”). Publication numbers were compiled annually

156 (1995-2016) and by ecology topic (as above). The search was conducted on September 20, 2017.

\section{Ocean Biogeographic Information System search}


159 Information System (OBIS, OBIS 2017) for the six representative marine taxa (Cnidaria,

160 Crustacea, Dinoflagellata, Echinodermata, Mollusca, and Pisces) with the aim of examining

161 spatial differences of readily available online data for these taxa within sub-regions. Using the

162 highest grid resolution of OBIS ( 0.1 degree), we examined all square grids that covered the

163 coastline of each island of the RYS and noted the number of records for each quadrat for each

164 taxon. The number of quadrats examined in each sub-region ranged from 11 in Miyako to 50 in

165 Okinawa (Table 1). The search was conducted in August 2017.

\section{Results}

\section{Web of Science taxa and sub-regions search}

examined 980 papers, which contained information for 1023 sub-region occurrences (some

Okinawa Main Island sub-region, 307 from an unspecified area in the RYS, 199 from Yaeyama,

48 from Amami Oshima, 29 from Yakutane, 16 from Miyako, and 4 from Tokara (Fig. 2). 
$175 n=51$, Dinoflagellata $n=44$; Fig. 2 ). Of note was the fact that $\sim 80 \%$ of both Echinodermata and

176 Dinoflagelleta papers were from Okinawa (40 of 51 papers, 36 of 44, respectively). Papers

177 dealing with Pisces were most numerous for Yakutane $(n=12)$, Okinawa $(n=82)$, and Yaeyama

$178(\mathrm{n}=80)$, while papers on Cnidaria were most numerous for Amami $(\mathrm{n}=19)$ and Okinawa $(\mathrm{n}=169)$,

179 and Cnidaria and Crustacea were equally numerous for Tokara ( $\mathrm{n}=2$ each) and Miyako ( $\mathrm{n}=6$

180 each). For unspecified sub-regions, Pisces $(n=118)$ and Crustacea $(n=108)$ were the most

181 numerous taxa (Fig. 2).

182 Web of Science ecology search and comparison

183 Our WoS search results showed that the RYS had fewer publications overall $(\mathrm{n}=1288$;

184 Fig. 3) when compared to the three other coral reef regions examined for the same time period

185 (GBR $n=6242$, CAB n=6990, RES n=4493). Additionally, RYS publication numbers were lower

186 for all eight ecological topics analyzed (Fig. 4). In particular, numbers for RYS were

187 comparatively very low for herbivory and marine protected areas (Fig. 4b and 4d, respectively).

188 Temporally, the number of papers published for all regions increased noticeably between 1995

189 and 2016 (Fig. 3), with the number of RYS papers increasing approximately 4.0 times (1995

$190 \mathrm{n}=24$ publications vs. $2016 \mathrm{n}=97), \mathrm{CAB}$ papers increasing 4.6 times $(1995 \mathrm{n}=100$ vs. 2016 
$191 \mathrm{n}=460)$, GBR papers increasing approximately 7.6 times (1995 $\mathrm{n}=66$ vs. $2016 \mathrm{n}=504)$, and RES

192 papers increasing approximately 8.4 times (1995 n=47 vs. $2016 n=397)$.

\section{Ocean Biogeographic Information System results}

195 showed great variation, with some general trends appearing. In general, the three more northern

196 sub-regions within Kagoshima Prefecture had fewer records than those in Okinawa Prefecture

197 for Cnidaria, Crustacea, Echinodermata, Mollusca, and Pisces. Within Okinawa Prefecture (and

198 the RYS), Okinawa consistently had the highest numbers of records, with the highest numbers

199 observed around Akajima (Crustacea, $n=200-500)$ and the west coast of Okinawa-jima Island

200 (Cnidaria, Crustacea, Echinodermata, Mollusca, and Pisces). Conversely, even within the

201 Okinawa sub-region, some areas such as the northeast coast of Okinawa-jima Island had none or

202 only few records (Electronic Supplementary Material Fig. S1a). Additionally, there was only one

203 record for the entire RYS within OBIS for Dinoflagellata in shallow water (Electronic

204 Supplementary Material Fig. S1b).

\section{Discussion}

From the WoS and OBIS analyses of sub-regions and taxa occurrences it became clear, 
207 as in many other marine regions (Hughes et al. 2002), that serious taxonomic and geographic

208 biases are present in marine research in the RYS. Some of this taxonomic bias may stem from

209 the commercial importance of Pisces and Crustacea in Japan, which has resulted in many studies

210 on various species' lifecycles and aquaculture methodologies (e.g. Nanami et al. 2010; Hamasaki

211 and Kitada 2008). Research on these topics, while often conducted somewhere in the RYS,

212 generally did not include field observations or sampling information as the focus was more on ex

213 situ analyses and model species. This was reflected in these two groups' dominance of the

214 "unspecified RYS sub-region" category as no specific location within the RYS was given within

215 these papers (Fig. 2). Another source of taxonomic and geographic bias likely stems from the

216 presence of specialist researchers, and this was more noticeable in relatively understudied

217 Echinodermata and Dinoflagellata, with one researcher each based in the Okinawa sub-region

218 contributing $>20 \%$ of the WoS research on each taxa (Echinodermata, $\mathrm{T}$ Uehara, 20/50 papers $=$

$21940 \%$; Dinoflagellata, S Suda, 9/44 papers $=20.5 \%$; both University of the Ryukyus).

221 with the large majority $(57.94 \%, n=135 / 233)$ on Scleractinia hard corals, and surprisingly far less

222 work on other commercially important groups such as Echinodermata and Mollusca. While 
223 Mollusca research was somewhat evenly spread around the RYS, approximately $80 \%$ of

224 Echinodermata research was conducted in the Okinawa sub-region, again due to the presence of

225 a specialist based in the region ( $\mathrm{T}$ Uehara, 20/50 papers $=40 \%$; also Fig. $2 \mathrm{~b}$ ). Due to recent

226 commercial pressure and reported large drops in abundances of some echinoderms (e.g. annual

227 Okinawa Prefecture harvest of Tripneustes gratilla sea urchin from $>700 \mathrm{t}$ in 1976 to $<50 \mathrm{t}$ in

228 late 1990s (Kakuma 2003), see also Soliman et al. (2016a, 2016b)), it is clear that more research

229 is urgently needed in other sub-regions. Hughes et al. (2002) suggested nearly two decades ago

230 that more work is needed on understudied small and cryptic coral reef taxa in understudied

231 locations, and this is still true for the RYS.

232 From the analyses of records of various taxa in OBIS, we can gain an indication of research patterns within each sub-region. While generally understudied sub-regions such as

234 Tokara had a lack of occurrence records for all taxa across all areas inside the sub-region, in the

235 case of more well-studied sub-regions, these areas were often directly adjacent to marine

236 research stations (e.g. 200-500 Crustacea occurrence records on Akajima, containing Akajima

237 Marine Station, active until 2017; Electronic Supplementary Material Fig. S1a) and have many

238 more occurrence records than in other areas. Thus, while Okinawa and Yaeyama can be 
239 considered to be comparatively well-studied inside RYS, there are areas within both sub-regions

240 that are almost completely uninvestigated. As conservation studies require occurrence data

241 across species ranges, research on these uninvestigated areas are a necessity. Additionally, the

242 presence of marine research stations is a driving force for research, and this is demonstrated by

243 the OBIS records for the Miyako sub-region, which despite a relatively large human population,

244 has no research-focused marine station (Table 1), and a corresponding general lack of scientific

245 publications and data available (e.g. Fig. 2).

247 it does not index all scientific journals, and its coverage in some fields is less complete than in

248 others. The lack of WoS coverage is particularly acute when examining English language marine

249 science publications from Japanese waters. Japan has a long history of marine biodiversity and

250 coral reef science (e.g. Kawaguti 1940), and even today much research is published in Japanese,

251 the large majority of which are in journals that do not appear in the WoS or any other central

252 online database. An exception is Nippon Suisan Gakkaishi, and even though it appears in the

253 WoS, some articles in this journal list title and authors only, with no abstract available in English,

254 and the journal even occasionally contains articles with no English at all. Such domestic journals 
255 are held in high regard in many scientific fields within Japan, including marine and fisheries

256 sciences, and contain much valuable and important data. Our initial analyses of Japanese

257 language literature suggest a strong bias towards fisheries (Pisces, some Crustacea) in the RYS

258 (data not shown). Failure to access these journals and their contents undoubtedly results in not

259 gaining a complete picture of marine sciences in Japan, including our examination here of

260 marine biodiversity in the RYS. We suggest that Japanese language science publications make

261 the effort to include translations of the title, authors, and abstract to allow more access from the

262 international science community, as is already performed by such journals as Nippon Suisan

263 Gakkaishi (for most articles, in the WoS) and Fauna Ryukyuana (for all articles, not in the WoS).

264 Additionally, for aquaculture or model species studies, listing the exact location from where

265 specimens were collected would be helpful for mapping records and distributions of species in

266 the Oceanographic Biology Information System (OBIS 2018) or other databases. Inclusion of

267 complete datasets online in repositories or as supplementary material would also greatly aid in

268 occurrence record mapping.

From the WoS search on ecological topics, the relative and comparative lack of

research in the RYS compared to the 'major' coral reef areas of CAB, GBR, and the RES is 
271 apparent. Our results were somewhat expected, particularly given the relatively small size of the

272 RYS (approximately $4642 \mathrm{~km}^{2}$ area and c. $1200 \mathrm{~km}$ in length) in comparison to the GBR, CAB

273 and RES (17,400 km² area c. $2300 \mathrm{~km}$ length; 10,530 $\mathrm{km}^{2}$ area; $8890 \mathrm{~km}^{2}$ area c. $2000 \mathrm{~km}$ length;

274 respectively, data from Berumen et al. (2013)); the coral reefs of the RYS are approximately half

275 the size of the next-smallest region RES. However, the amount of research conducted in area is

276 not a direct function of the size of coral reefs in any region. On the other hand, in terms of human

277 populations immediately adjacent to reefs, the RYS (Table 1) could be considered to have higher

278 numbers than those the GBR or even the RES, particularly given that the other three regions

279 have continental landmasses much larger than those of the RYS islands. The RYS also have an

280 abundance of marine research institutions (Fig. 1, Table 1).

281 When examining the trends for the different ecological topics, the deficiencies of

282 research in the RYS become starkly clear, with almost no research conducted on ecosystem

283 sciences such as herbivory, or on marine protected areas (Fig. 4). Historically, Japan and

284 Okinawa have been somewhat slow to adopt marine conservation measures with legal strength

285 (Reimer et al. 2015), and there are still no no-take zones in the RYS. It also appears from our

286 results that scientists based in the region have been equally slow to adopt research on these topics, 
287 despite a public need for such third-party research given the controversy over continuing coastal

288 development in Okinawa (McCormack 1999; Hook 2010). Additionally, and somewhat

289 surprisingly, there has been little research on apex predators, despite high public interest in Japan

290 in this group (e.g. world-famous shark displays at Churaumi Aquarium in Okinawa, visited by

$291>3,000,000$ people/year; Churaumi Aquarium 2018)). Given the high rates of marine endemism

292 and biodiversity in this region (Roberts et al. 2002), more efforts should be made to conduct

293 research on these topics in the RYS.

296 national universities include a Faculty of Fisheries (e.g. Kagoshima University, national

university for Kagoshima Prefecture containing Yakutane, Tokara, and Amami island regions).

298 Thus, there may be a general bias in research and instruction towards fisheries-related species,

299 possibly at the expense of other marine biodiversity research and taxa. More capacity building

300 and investment are needed in other fields, such as non-fisheries-related marine biodiversity,

301 marine ecology, and marine conservation, as our results demonstrate. 
303 (Bornmann and Mutz 2015), and marine science is no exception. However, worryingly, the pace

304 at which marine scientific research in the RYS has increased has not kept pace with the other

305 three regions we examined (Fig. 3). While numbers of publications from the RYS (and all other

306 regions) are increasing, given the large number of coral reef, fisheries, and marine science

307 researchers in Japan (e.g. the Japanese Coral Reef Society created in 1997 has over 600 members

308 [JCRS homepage http://www.jcrs.jp]), we expected the gap between the RYS and other regions

309 to be smaller. At current rates and based on these data from the past twenty-one years, compared

310 to other regions the RYS are comparatively less studied now than in 1995.

\section{Conclusions}

312 In conclusion, marine biodiversity and ecology research in the RYS, while steadily

313 advancing, lags behind the progress of other major coral reef regions in the world. In particular,

314 research levels on conservation topics are dramatically lower than in other coral reef regions,

315 despite the need for conservation and protection of these ecosystems (Fig. 4). Additionally,

316 despite the large amount of marine research infrastructure including numerous research facilities

317 and a large population base, and despite the comparatively small area of the RYS (Table 1), there

318 are taxa in both sub-regions and smaller areas within sub-regions that are almost completely 
319 unstudied. Moving forward, local, prefectural, and national governments and stakeholders should

320 focus on addressing the gaps in our knowledge base. Marine biodiversity research in the RYS

321 will benefit from continuing to build international collaborative research projects to broaden the

322 breadth of taxonomic studies and also the scope of ecosystem-based and conservation planning

323 studies. Such works combined with a more robust legal framework and the establishment of

324 functioning no-take and marine protected areas should be able to better conserve and protect

325 RYS coral reef ecosystems and their valuable ecosystem services for future generations (Table 2).

\section{Acknowledgements}

328 Marine Biodiversity", taught by the first author in 2017, and part of the Okinawa International

329 Marine Science Program (OIMAP) at the Graduate School of Engineering and Science at the

330 University of the Ryukyus (UR). This work was partially inspired by a Red Sea biodiversity

331 research overview by Berumen et al. (2013). This article was prepared as a class project by the

332 members of a $\mathrm{PhD}$ program with all authors contributing equally to produce the research and the

333 end product of the article. They have also been named in alphabetical order to reflect their equal

334 contributions. We thank Drs. T. Naruse (UR) and T. Fujii (Kagoshima University) for 
335 information on marine research institutes in the RYS. Three reviewers greatly improved an

336 earlier version of this manuscript.

\section{References}

338 Andres M, Park JH, Wimbush M, Zhu XH, Chang KI, Ichikawa H (2008) Study of the

339

340

341

342

343

344

345

346

347

348

349

350

351

352

353

354

355

356

357

358

359

360

361

362

363

Kuroshio/Ryukyu current system based on satellite-altimeter and in situ measurements. J

Oceanogr 64:937-950. doi: 10.1007/s10872-008-0077-2

Appeltans W, Ahyong ST, Anderson G, Angel MV, Artois T, Bailly N, Bamber R, Barber A, Bartsch I, Berta A, Błażewicz-Paszkowycz M, Bock P, Boxshall G, Boyko CB, Brandão SN, Bray RA, Bruce NL, Cairns SD, Chan TY, Cheng L, Collins AG, Cribb T, CuriniGalletti M, Dahdouh-Guebas F, Davie PJ, Dawson MN, De Clerck O, Decock W, De Grave S, de Voogd NJ, Domning DP, Emig CC, Erséus C, Eschmeyer W, Fauchald K, Fautin DG, Feist SW, Fransen CH, Furuya H, Garcia-Alvarez O, Gerken S, Gibson D, Gittenberger A, Gofas S, Gómez-Daglio L, Gordon DP, Guiry MD, Hernandez F, Hoeksema BW, Hopcroft RR, Jaume D, Kirk P, Koedam N, Koenemann S, Kolb JB, Kristensen RM, Kroh A, Lambert G, Lazarus DB, Lemaitre R, Longshaw M, Lowry J, Macpherson E, Madin LP, Mah C, Mapstone G, McLaughlin PA, Mees J, Meland K, Messing CG, Mills CE, Molodtsova TN, Mooi R, Neuhaus B, Ng PK, Nielsen C, Norenburg J, Opresko DM, Osawa M, Paulay G, Perrin W, Pilger JF, Poore GC, Pugh P, Read GB, Reimer JD, Rius M, Rocha RM, Saiz-Salinas JI, Scarabino V, Schierwater B, Schmidt-Rhaesa A, Schnabel KE, Schotte M, Schuchert P, Schwabe E, Segers H, SelfSullivan C, Shenkar N, Siegel V, Sterrer W, Stöhr S, Swalla B, Tasker ML, Thuesen EV, Timm T, Todaro MA, Turon X, Tyler S, Uetz P, van der Land J, Vanhoorne B, van Ofwegen LP, van Soest RW, Vanaverbeke J, Walker-Smith G, Walter TC, Warren A, Williams GC, Wilson SP, Costello MJ (2012) The magnitude of global marine species diversity. Curr Biol 22(23):2189-2202.

Bellard C, Bertelsmeier C, Leadley P, Thuiller W, Courchamp F (2012) Impacts of climate change on the future of biodiversity. Ecol Lett 15:365-377. doi: 10.1111/j.14610248.2011.01736.x.Impacts

Berumen M, Hoey A, Bass W, Bouwmeester J, Catania D, Cochran JEM, Khalil MT, Miyake S, 
364

365

366

367

368

369

370

371

372

373

374

375

376

377

378

379

380

381

382

383

384

385

386

387

388

389

390

391

392

393

394

395

Mughal MR, Spaet JLY, Saenz-Agudelo P (2013) The status of coral reef ecology research in the Red Sea. Coral Reefs 32:737-748. doi: 10.1007/s00338-013-1055-8

Bornmann L, Mutz R (2015) Growth rates of modern science: A bibliometric analysis based on the number of publications and cited references. J Assoc Info Sci Tech. 66:2215-2222. doi: $\underline{10.1002 / a s i .23329}$

Cardinale BJ, Duffy JE, Gonzalez A, Hooper DU, Perrings C, Venail P, Narwani A, Mace GM, Tilman D, Wardle DA, Kinzig AP, Daily GC, Loreau M, Grace JB, Larigauderie A, Srivastava DS, Naeem S (2012) Biodiversity loss and its impact on humanity. Nature 489:326-326. doi: 10.1038/nature11373

Chapin FS, Zavaleta ES, Eviner VT, Naylor RL, Vitousek PM, Reynolds HL, Hooper DU, Lavorel S, Sala OE, Hobbie SE, Mack MC, Díaz S (2000) Consequences of changing biodiversity. Nature 405:234-242.

Costanza R, Arge R, de Groot R, Farber S, Grasso M, Hannon B, Limburg K, Naeem S, O'Neil RV, Paruelo J, Raskin RG, Sutton P, van den Belt M (1997) The value of the world's ecosystem services and natural capital. Nature 387:253-260. doi: 10.1038/387253a0

Costello MJ, May RM, Stork NE (2013) Can we name Earth's species before they go extinct? Science 339:413-416. doi: 10.1126/science.1230318

Cowman PF, Parravicini V, Kulbicki M, Floeter SR (2017) The biogeography of tropical reef fishes: Endemism and provinciality through time. Biol Rev 92:2112-2130. doi: $10.1111 /$ brv. 12323

Dal Kee H (2015) Sustainability of ecotourism in Yakushima, Japan. Japanese Cultural Studies 54:331-352.

Duffy JE, Godwin CM, Cardinale BJ (2017) Biodiversity effects in the wild are common and as strong as key drivers of productivity. Nature 549:261. doi: 10.1038/nature23886

Dunne J, Williams RJ, Martinez ND (2002) Network structure and biodiversity loss in food webs: robustness increases with connectance. Ecol Lett 5:558-567. doi: 10.1046/j.14610248.2002.00354.x

Fujii T (2016) Preliminary report of diversity of order Zoantharia and Actiniaria in the Satsunan Islands, Kagoshima. Kagoshima University Occasional Papers 57:87-88 (in Japanese).

Fujii S, Kubota Y, Enoki T (2009) Resilience of stand structure and tree species diversity in subtropical forest degraded by clear logging. J For Res 14:373-387. doi: 10.1007/s10310009-0151-7 
396 Fujikura K, Lindsay D, Kitazato H, Nishida S, Shirayama Y (2010) Marine biodiversity in

397 Japanese waters. PLoS One 5:e11836. doi: 10.1371/journal.pone.0011836

398 Fujita K, Arakaki T, Denda T, Hidaka M, Hirose E, Reimer JD (eds) (2015) Nature in the Ryukyu Archipelago: coral reefs, biodiversity, and the natural environment, Faculty of Science, University of the Ryukyus, Nishihara.

401

Geospatial Information Authority of Japan (2017) Heisei 29 national prefectural, city, town,

402 village area survey form 3 (October 1, 2017 version) (in Japanese)

403 http://www.gsi.go.jp/KOKUJYOHO/MENCHO/201710/f3_shima.pdf

Hamasaki K, Kitada S (2008) Potential of stock enhancement for decapod crustaceans. Rev Fish 405 Sci 16:164-174.

Hasegawa H, Yamano H (2004) Ishigaki Island. In: Japanese Coral Reef Society (ed) Coral Reefs of Japan, Ministry of the Environment, Japan, 1 edn. pp 210-218.

Hirano N, Kakutani N (2015) Improvements of systems for accepting tourists to Okinawa in accordance with increases in LCC users. Northeast Asia Tourism Research 11:241-266.

Hook GD (2010) Intersecting risks and governing Okinawa: American bases and the unfinished war. Japan Forum 22:195-217.

412 Hughes TP, Bellwood DR, Connolly SR (2002) Biodiversity hotspots, centres of endemicity, and the conservation of coral reefs. Ecol Lett 5:775-784. doi: 10.1046/j.14610248.2002.00383.x

Kagoshima Prefecture (2017) Heisei 29 population report (in Japanese). https://www.pref.kagoshima.jp/ac09/tokei/bunya/jinko/jinkouidoutyousa/nennpou/h29.htm 1

Kajiwara K, Matsumoto H (2004) Miyako Archipelago. In: Japanese Coral Reef Society (ed) Coral Reefs of Japan, Ministry of the Environment, Japan, 1 edn. pp 202-208.

Kakuma S (2003) Coral reef fisheries management in tropic and subtropic regions. Galaxea JCRS 5:69-77.

Kawaguti S (1940) Materials for the study of reef-building corals (1). Science of the South Sea (Kagaku Nanyo) 2:159-169. In: S. Kawaguti Working Group of the Japanese Coral Reef Society (JCRS) (eds) Reports by Dr. Siro Kawaguti during his stay in the Palao (Palau) 426 Tropical Biological Station in 1936-1940 (English translation). Galaxea JCRS 14S:13-25. 
428 Kizaki K (1986) Geology and tectonics of the Ryukyu Islands. Tectonophysics 125:193-207.

429 doi: 10.1016/0040-1951(86)90014-4

430 Mace GM, Norris K, Fitter AH (2012) Biodiversity and ecosystem services: A multilayered 431 relationship. Trends Ecol Evol 27:19-25. doi: 10.1016/j.tree.2011.08.006

432 McCormack G (1999) From the sea that divides to the sea that links: contradictions of ecological 433 and economic development in Okinawa. Capitalism Nat Socialism 10:3-40.

434 Nakae M, Motomura H, Hagiwara K, Senou H, Koeda K, Yoshida T, Tashiro S, Jeong B, Hata H, 435 Fukui Y, Fujiwara K, Yamakawa T, Aizawa M, Shinohara G, Matsuura K (2018) An annotated checklist of fishes of Amami-Oshima Island, the Ryukyu Islands, Japan. Mem Natl Mus Nat Sci Tokyo 52: 205-361.

Nakai T, Nojima S (2004) Osumi Islands and Tokara Archipelago. In: Japanese Coral Reef Society (ed) Coral Reefs of Japan, Ministry of the Environment, Japan, 1 edn. pp 164-169.

Nakai T, Oki K (2004) Amami Archipelago. In: Japanese Coral Reef Society (ed) Coral Reefs of Japan, Ministry of the Environment, Japan, 1 edn. pp 170-174.

Nakano Y (2004a) Direct impacts of coastal development. In: Japanese Coral Reef Society (ed) Coral Reefs of Japan, Ministry of the Environment, Japan, 1 edn. pp 60-63.

Nakano Y (2004b) Global environmental change and coral bleaching. In: Japanese Coral Reef Society (ed) Coral Reefs of Japan, Ministry of the Environment, Japan, 1 edn. pp 42-48.

Nanami A, Okuzawa K, Yamada H, Suzuki N, Aonuma Y (2010) Reproductive activity in the checkered snapper, Lutjanus decussatus, off Ishigaki Island, Okinawa. Ichthyol Res 57:314-318.

Nishihira M (2004) Hermatypic corals of Japan. In: Japanese Coral Reef Society (ed) Coral Reefs of Japan, Ministry of the Environment, Japan, 1 edn. pp 10-13.

Nishihira M, Veron JE (1995) Hermatypic corals of Japan. Kaiyusha, Tokyo. 439 pp.

OBIS (2017) Ocean Biogeographic Information System. Intergovernmental Oceanographic Commission of UNESCO. www.iobis.org

454 Okinawa Churaumi Aquarium (2018). Experiencing the vast waters surrounding Okinawa at Okinawa Churaumi Aquarium. Accessed in October 2018. https://www.visitokinawa.jp/information/okinawa-churaumi-aquarium

Okinawa Prefectural Government (2016) A summary of inbound tourist statistics in 2015 
460

461

462

463

464

465

466

467

468

469

470

471

472

473

474

475

476

477

478

479

480

481

482

483

484

485

486

487

488

489

490

491

sports/kankoseisaku/kikaku/statistics/tourists/documents/h27-f-gaikyou.pdf

Okinawa Prefecture (2018) Okinawa prefecture statistical material, Census Report 2018/11, Population Social Statistics team, Naha, Okinawa.

URL https://www.pref.okinawa.jp/toukeika/estimates/2018/pop201811.pdf

Okubo N, Onuma A (2015) An economic and ecological consideration of commercial coral transplantation to restore the marine ecosystem in Okinawa, Japan. Ecosyst Serv 11:39-44. doi: 10.1016/j.ecoser.2014.07.009

Reimer JD, Yang SY, White KN, Asami R, Fujita K, Hongo C, Ito S, Kawamura I, Maeda I, Mizuyama M, Obuchi M, Sakamaki T, Tachihara K, Tamura M, Tanahara A, Yamaguchi A, Jenke-Kodama H (2015) Effects of causeway construction on environment and biota of subtropical tidal flats in Okinawa, Japan. Mar Pollut Bull 94:153-167. doi: 10.1016/j.marpolbul.2015.02.037

Roberts CM, Mittermeier CG, Schueler FW (2002) Marine biodiversity hotspots and conservation priorities for tropical reefs. Science 295:1280-1285. doi:

$10.1126 /$ science. 1067728

Ryukyu Shimpo (2018) Okinawa tourists exceeding Hawaii, last year 9.39 million people, foreigners increased significantly. February 2, 2018. https://ryukyushimpo.jp/news/entry657773.html (in Japanese)

Sakai K (2004). Okinawa Island. In: Japanese Coral Reef Society (ed) Coral Reefs of Japan, Ministry of the Environment, Japan, 1 edn. pp 178-193.

Shimoike K (2004) Sekisei Lagoon. In: Japanese Coral Reef Society (ed) Coral Reefs of Japan, Ministry of the Environment, Japan, 1 edn. pp 219-224.

Shimomura M, Fujita Y, Naruse T (2012) First record of the genus Thetispelecaris Guţu \& Illife, 1998 (Crustacea: Peracarida: Bochusacea) from a submarine cave in the Pacific Ocean. In: Naruse T, Chan TY, Tan HH, Ahyong ST, Reimer JD (eds), Scientific results of the Kumejima Marine Biodiversity Expedition-KUMEJIMA 2009. Zootaxa 3367:69-78.

Soliman T, Fernandez-Silva I, Reimer JD (2016a) Genetic population structure and low genetic diversity in the over-exploited sea cucumber Holothuria edulis Lesson, 1830 (Echinodermata: Holothuroidea) in Okinawa Island. Cons Gen 17:811-821.

Soliman T, Takama O, Fernandez-Silva I, Reimer JD (2016b) Extremely low genetic variability within and among locations of the greenfish holothurian Stichopus chloronotus Brandt, 1835 in Okinawa, Japan. PeerJ 4:e2410. 
492 Tada O (2015) Constructing Okinawa as Japan's Hawaii: from honeymoon boom to resort 493 paradise. Japanese Stud 35:287-302. doi: 10.1080/10371397.2015.1124745

494 Toonen RJ, Bowen BW, Iacchei M, Briggs JC (2016) Biogeography, Marine. In: Kliman RM 495 (ed) Encyclopedia of Evolutionary Biology, 1st edn. pp 166-178.

496 Toyoshima J, Nadaoka K (2015) Importance of environmental briefing and buoyancy control on 497 reducing negative impacts of SCUBA diving on coral reefs. Ocean Coast Manag 116:20498 26. doi: 10.1016/j.ocecoaman.2015.06.018

499 Troudet J, Grandcolas P, Blin A, Vignes-Lebbe R, Legendre F (2017) Taxonomic bias in 500

501 biodiversity data and societal preferences. Sci Rep 7:9132. doi: 10.1038/s41598-017-

502 09084-6

Veron JEN (1992) Conservation of biodiversity: a critical time for the hermatypic corals of Japan. 503 Coral Reefs 11:13-21. doi: 10.1007/BF00291930

Yokochi H (2004a) Iriomote Island and neighboring islands. In: Japanese Coral Reef Society (ed) Coral Reefs of Japan, Ministry of the Environment, Japan, 1 edn. pp 225-229.

506 Yokochi H (2004b) Predation damage to corals. In: Japanese Coral Reef Society (ed) Coral Reefs of Japan, Ministry of the Environment, Japan, 1 edn. pp 49-55.

508

509

\section{Tables}

510 Table 1 - Information on the six sub-regions investigated in this study in the Ryukyu Islands

511 (RYS).

512 Table 2 - Summary of key research priorities to support marine biodiversity, marine ecology, and

513 marine conservation in the Ryukyus (RYS).

\section{Figures}

515 Figure 1 - Map of the Ryukyu Islands (RYS) with sub-regions examined in this study, and

516 relevant geographic features and research institutions (red stars). Airport symbols next to island 
517 names indicate presence of airport.

518 Figure 2 - (a) Total number of publications in the Web of Science (1995-2017) for six different

519 marine taxa (Pisces, Crustacea, Echinodermata, Cnidaria, Porifera, Dinoflagellata) for each sub-

520 region in the RYS as well as for undetermined locations and overall total, and (b) the breakdown

521 of these publications by marine taxa. Reference map of the RYS included on the left side.

522 Figure 3 - (a) Numbers of ecological publications per year, and (b) the total number of

523 publications for the Ryukyus (RYS; blue), Red Sea (RES, red), Great Barrier Reef (GBR, grey),

524 and Caribbean (CAR, yellow) from 1995 to 2016 in the Web of Science.

525 Figure 4 - Number of ecological publications per year for four regions from 1995 to 2016 in the

526 Web of Science; the Ryukyus (RYS; blue), Red Sea (RES, red), Great Barrier Reef (GBR, grey),

527 and Caribbean (CAR, yellow) by topic. (a) apex predators, (b) herbivory, (c) connectivity, (d)

528 marine protected areas, (e) coral bleaching, (f) Porifera, (g) coral reproduction, and (h) reef-

529 associated bacteria.

530 Electronic Supplementary Material

531 Electronic Supplementary Material Table S1 - search terms for Web of Science and numbers of

532 publications per year (1995-2017) for the Ryukyus, Red Sea, Great Barrier Reef, and Caribbean. 
533 Electronic Supplementary Material Figure S1 - Example images of the Okinawa sub-region of

534 the RYS within the Ocean Biogeographic Information System (OBIS) for (a) Crustacea, and (b)

535 Dinoflagellata, showing spatial differences in the records of these taxa. Crustacea have most

536 numerous records $(\mathrm{n}=200-500)$ in the square that contains Akajima Marine Station. On the other

537 hand, there are almost no data for Dinoflagellata. The search was conducted in August 2017. 


\section{Table $\mathbf{1}$ (on next page)}

Table 1 - Information on the six sub-regions investigated in this study in the Ryukyu Islands (RYS).

Information on the six sub-regions investigated in this study in the Ryukyu Islands (RYS). 
1 Table 1 - Information on the six sub-regions investigated in this study in the Ryukyu Islands (RYS).

\begin{tabular}{|c|c|c|c|c|c|c|c|c|}
\hline Sub-region & Yakutane & Tokara & Amami & Okinawa & Miyako & Yaeyama & RYS total & Reference( \\
\hline Major islands & $\begin{array}{l}\text { Yakushima, } \\
\text { Tanegashima, } \\
\text { Kuchinoerabu, } \\
\text { others }\end{array}$ & $\begin{array}{c}\text { Nakanoshima, } \\
\text { Suwanose, } \\
\text { Kuchinoshima, Taira, } \\
\text { Takara, Kodakara, } \\
\text { Akuseki, others }\end{array}$ & $\begin{array}{l}\text { Amami-Oshima, } \\
\text { Kikai, Tokunoshima, } \\
\text { Okinoerabu, Yoron, } \\
\text { others }\end{array}$ & $\begin{array}{c}\text { Okinawa Main } \\
\text { Island, Kume, Izena, } \\
\text { Iheya, Kerama } \\
\text { Islands, Ikei Islands, } \\
\text { Aguni, le, Sesoko, } \\
\text { Kouri, others }\end{array}$ & $\begin{array}{l}\text { Miyako, Ikema, } \\
\text { Tarama, others }\end{array}$ & $\begin{array}{l}\text { Ishigaki, Iriomote, } \\
\text { Taketomi, others }\end{array}$ & $\begin{array}{c}198 \text { islands (not } \\
\text { including }<0.01 \\
\text { km2) }\end{array}$ & NA \\
\hline $\begin{array}{l}\text { Notable marine } \\
\text { research stations } \\
\& \text { institutes }\end{array}$ & $\begin{array}{l}\text { Yakushima } \\
\text { Umigane-kan }\end{array}$ & none & $\begin{array}{c}\text { Kagoshima } \\
\text { University Amami } \\
\text { Station, Seikai } \\
\text { National Fisheries } \\
\text { Research Institute } \\
\text { Amami Station, Kikai } \\
\text { Coral Reef Research } \\
\text { Institute (from 2014), } \\
\text { Kagoshima U. Fac. } \\
\text { Fisheries Yoron } \\
\text { Station }\end{array}$ & $\begin{array}{l}\text { Akajima Marine } \\
\text { Science Laboratory } \\
\text { (closed 2017), } \\
\text { Okinawa Institute of } \\
\text { Science and } \\
\text { Technology (from } \\
\text { 2011), Okinawa } \\
\text { National College of } \\
\text { Technology, } \\
\text { University of the } \\
\text { Ryukyus Tropical } \\
\text { Biosphere Research } \\
\text { Center Sesoko } \\
\text { Station, University of }\end{array}$ & $\begin{array}{l}\text { Miyakojima City } \\
\text { Museum }\end{array}$ & $\begin{array}{l}\text { University of the } \\
\text { Ryukyus Iriomote } \\
\text { Field Station, } \\
\text { Ishigaki Pref. Exp. } \\
\text { Station, Ishigaki MoE } \\
\text { Parks Station, } \\
\text { Kuroshima Sea } \\
\text { Turtle Station }\end{array}$ & & $\begin{array}{r}\text { Various institl } \\
\text { homepage }\end{array}$ \\
\hline
\end{tabular}




\begin{tabular}{|c|c|c|c|c|c|c|c|c|}
\hline & & & & $\begin{array}{l}\text { the Ryukyus Main } \\
\text { Campus, Itoman } \\
\text { Pref. Exp. Center, } \\
\text { Meio University }\end{array}$ & & & & \\
\hline $\begin{array}{l}\text { OBIS cover (\# } \\
\text { squares) }\end{array}$ & 27 & 14 & 36 & 50 & 11 & 26 & 164 & OBIS \\
\hline Land area $\left(\mathbf{k m}^{2}\right)$ & 1030 & 101.35 & 1231.47 & 1418.59 & 226.5 & 587.16 & 4595.07 & $\begin{array}{r}\text { Informatio } \\
\text { Authority of Jc } \\
\text { (2017) }\end{array}$ \\
\hline Population & 41,870 & 768 & 107,238 & $1,341,553$ & 52,456 & 54,092 & $1,597,977$ & $\begin{array}{r}\text { Prefecture (2 } \\
\text { Okinawo } \\
\text { Prefecture (2 }\end{array}$ \\
\hline $\begin{array}{l}\text { Population } \\
\text { density }\left(/ \mathbf{k m}^{2}\right)\end{array}$ & 40.7 & 7.6 & 87.1 & 945.7 & 231.6 & 92.1 & 347.8 & NA \\
\hline $\begin{array}{l}\text { Geological } \\
\text { formation }\end{array}$ & $\begin{array}{c}\text { volcanic, } \\
\text { sedimentary, } \\
\text { granite uplift }\end{array}$ & volcanic, coral reefs & $\begin{array}{c}\text { volcanic, } \\
\text { sedimentary, uplift, } \\
\text { coral reefs }\end{array}$ & $\begin{array}{c}\text { volcanic, } \\
\text { sedimentary, uplift, } \\
\text { coral reefs }\end{array}$ & volcanic, coral reefs & $\begin{array}{c}\text { volcanic, } \\
\text { sedimentary, uplift, } \\
\text { coral reefs }\end{array}$ & $N / A$ & $\begin{array}{r}\text { Kayane et a } \\
(2004)), \text { Fujit } \\
\text { al. (2015) }\end{array}$ \\
\hline
\end{tabular}




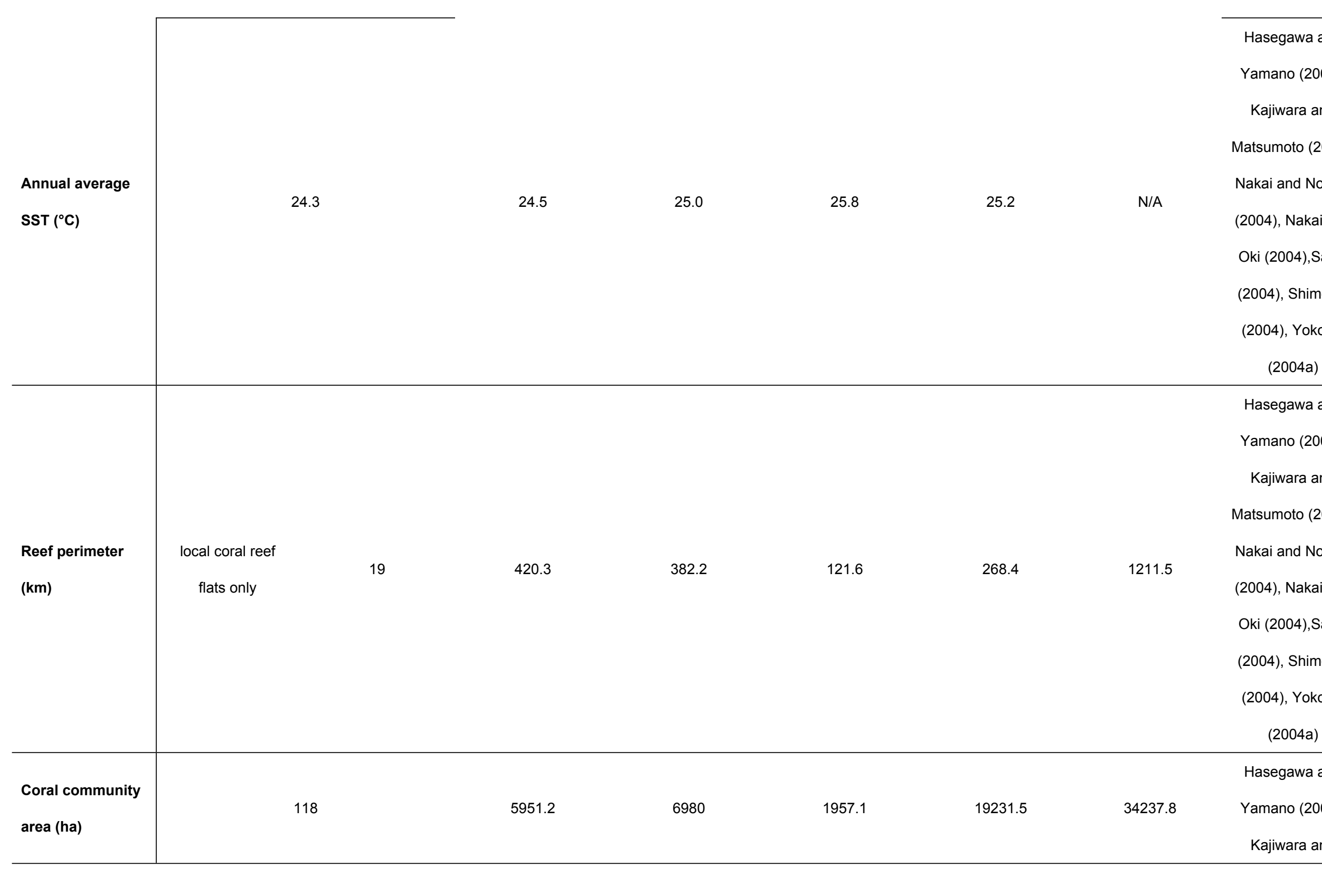




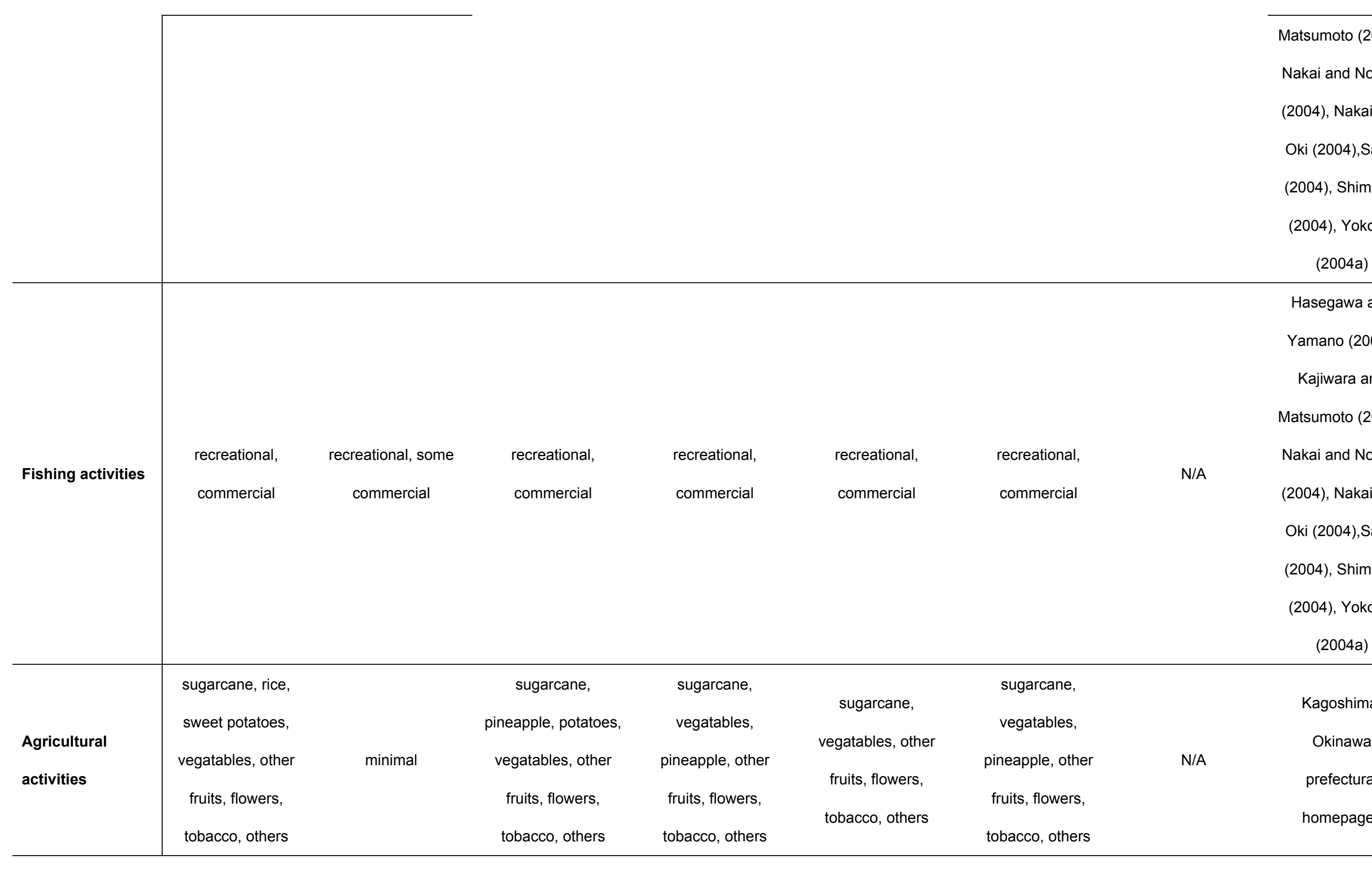




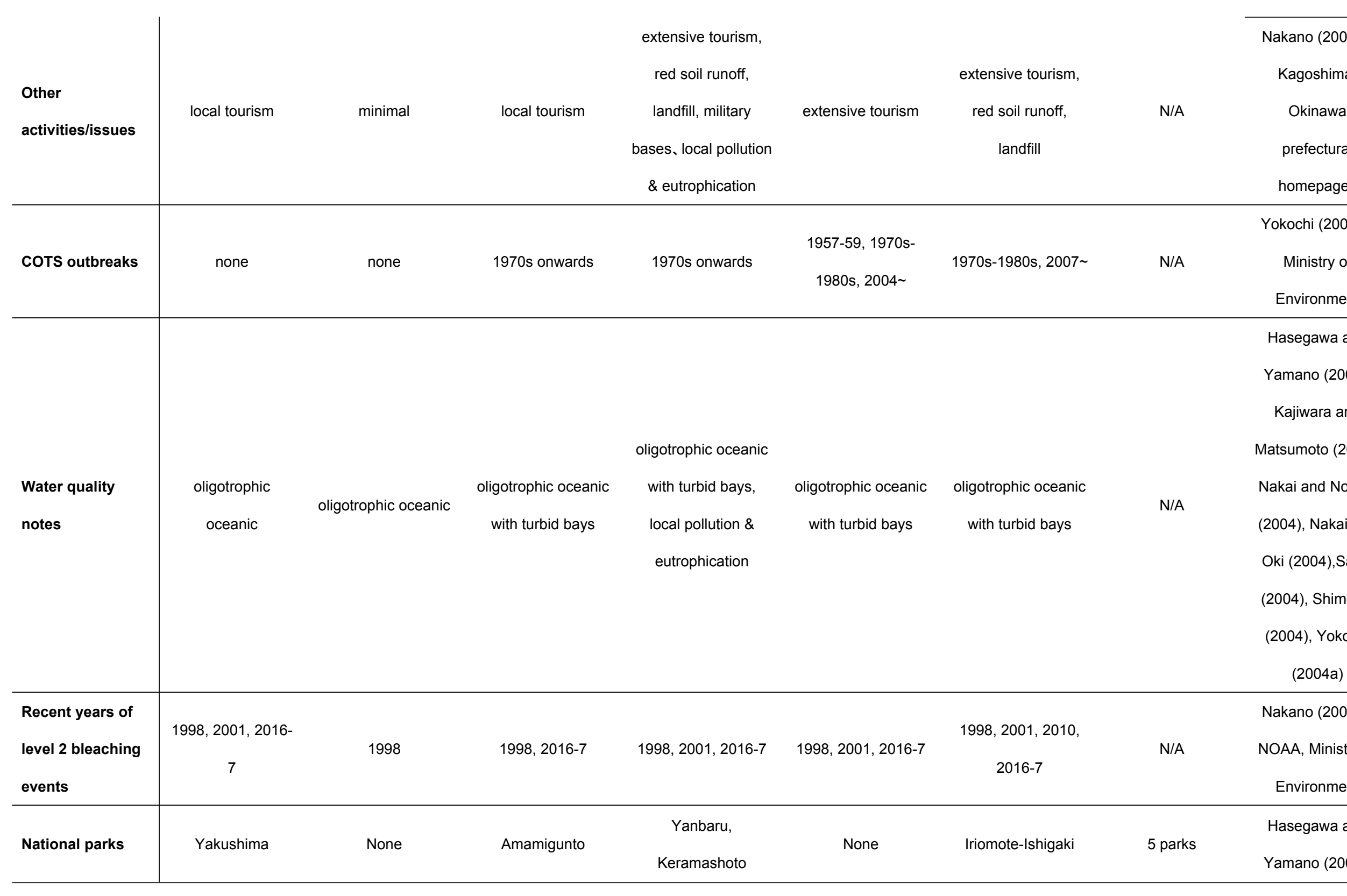




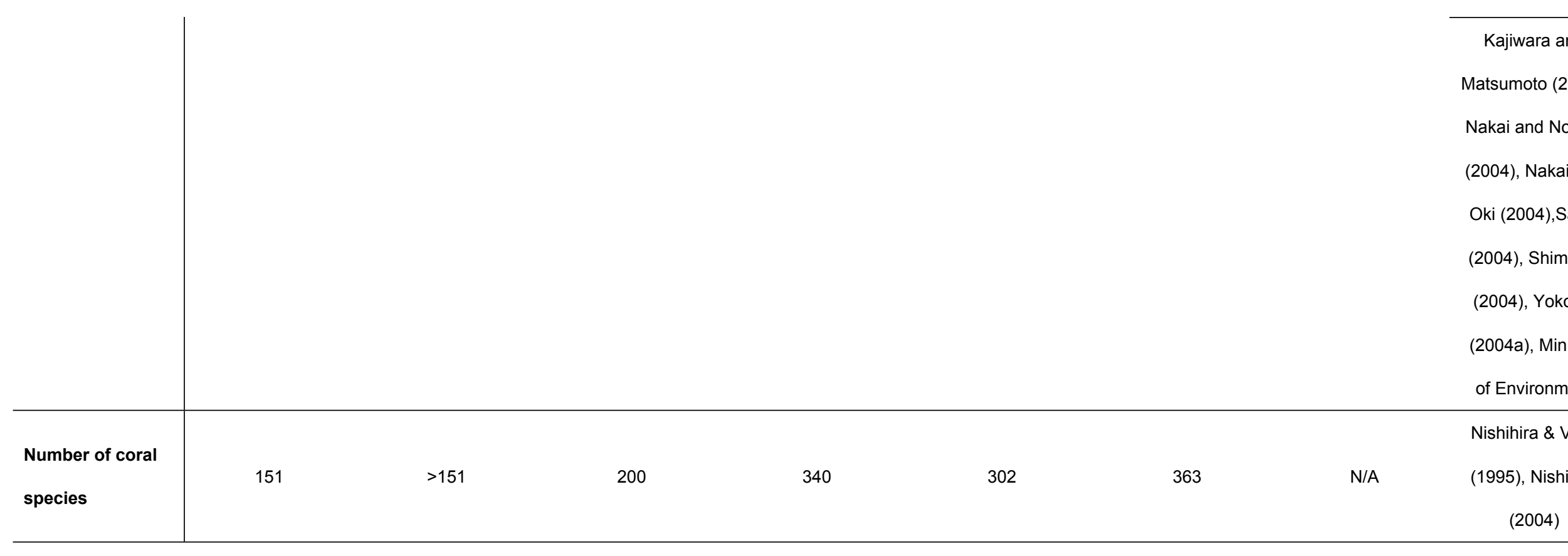


Table 2 (on next page)

Summary of key research priorities to support marine biodiversity, marine ecology, and marine conservation in the Ryukyus (RYS). 
2 Table 2. Summary of key research priorities to support marine biodiversity, marine ecology, and marine conservation in the Ryukyus (RYS).

\begin{tabular}{|c|c|c|}
\hline Research priority & Cause(s)/source(s) of need & Achievability rank (1 (low) - 5 (high)) + comments \\
\hline $\begin{array}{l}\text { More research on } \\
\text { Yakutane, Miyako and } \\
\text { Tokara island groups }\end{array}$ & Low numbers of publications. & 4. Dependent on funding to organize expeditions. \\
\hline $\begin{array}{l}\text { More research on } \\
\text { Dinoflagellata }\end{array}$ & $\begin{array}{l}\text { Least studied taxon }(n=44) \text {, of ecological interest } \\
+ \text { importance. }\end{array}$ & $\begin{array}{l}\text { 3. Requires taxonomists and chemical and molecular } \\
\text { equipment. Some taxa impossible to keep in culture. }\end{array}$ \\
\hline $\begin{array}{l}\text { More research on } \\
\text { Echinodermata }\end{array}$ & $\begin{array}{l}\text { Understudied }(\mathrm{n}=51) \text {. Most studies only around } \\
\text { Okinawa Island. Includes coral predators and } \\
\text { species of economic interest, potentially } \\
\text { threatened. }\end{array}$ & 4. Requires taxonomists and molecular equipment. \\
\hline $\begin{array}{l}\text { More research on } \\
\text { Mollusca }\end{array}$ & $\begin{array}{l}\text { Relatively understudied }(\mathrm{n}=92) \text {. Includes coral } \\
\text { predators and species of economic interest, } \\
\text { potentially threatened. }\end{array}$ & 4. Requires taxonomists and molecular equipment. \\
\hline $\begin{array}{l}\text { More studies on } \\
\text { 'herbivory' and 'apex } \\
\text { predators' }\end{array}$ & $\begin{array}{l}\text { Important in marine conservation. Understudied in } \\
\text { the RYS. Herbivores and apex predators } \\
\text { potentially threatened/overharvested. }\end{array}$ & 5. Requires scientists focused on these topics. \\
\hline $\begin{array}{l}\text { More studies on marine } \\
\text { protected areas (MPAs) }\end{array}$ & Critical for marine conservation. & $\begin{array}{l}\text { 2. Requires functioning MPAs. In Japan, no-take-zones } \\
\text { are currently absent. }\end{array}$ \\
\hline $\begin{array}{l}\text { Implementation of new } \\
\text { MPAs. }\end{array}$ & Critical for marine conservation. & $\begin{array}{l}\text { 1. MPAs are still largely seen negatively. More effort } \\
\text { should be invested in public outreach and education. }\end{array}$ \\
\hline $\begin{array}{l}\text { Making Japanese literature } \\
\text { more accessible. }\end{array}$ & $\begin{array}{l}\text { Science should be accessible by international } \\
\text { scientific community. Possibility of increased } \\
\text { international collaboration and funding. }\end{array}$ & $\begin{array}{l}\text { 5. Requiring at least title and abstract submitted in } \\
\text { English should be feasible for scientific journals. Some } \\
\text { journals already do this. Encourage publishing in } \\
\text { English. Research institutions should provide language } \\
\text { support. }\end{array}$ \\
\hline
\end{tabular}




\section{Figure 1}

Map of the Ryukyu Islands (RYS).

Map of the Ryukyu Islands (RYS) with sub-regions examined in this study, and relevant geographic features and research institutions (red stars). Airport symbols next to island names indicate presence of airport.

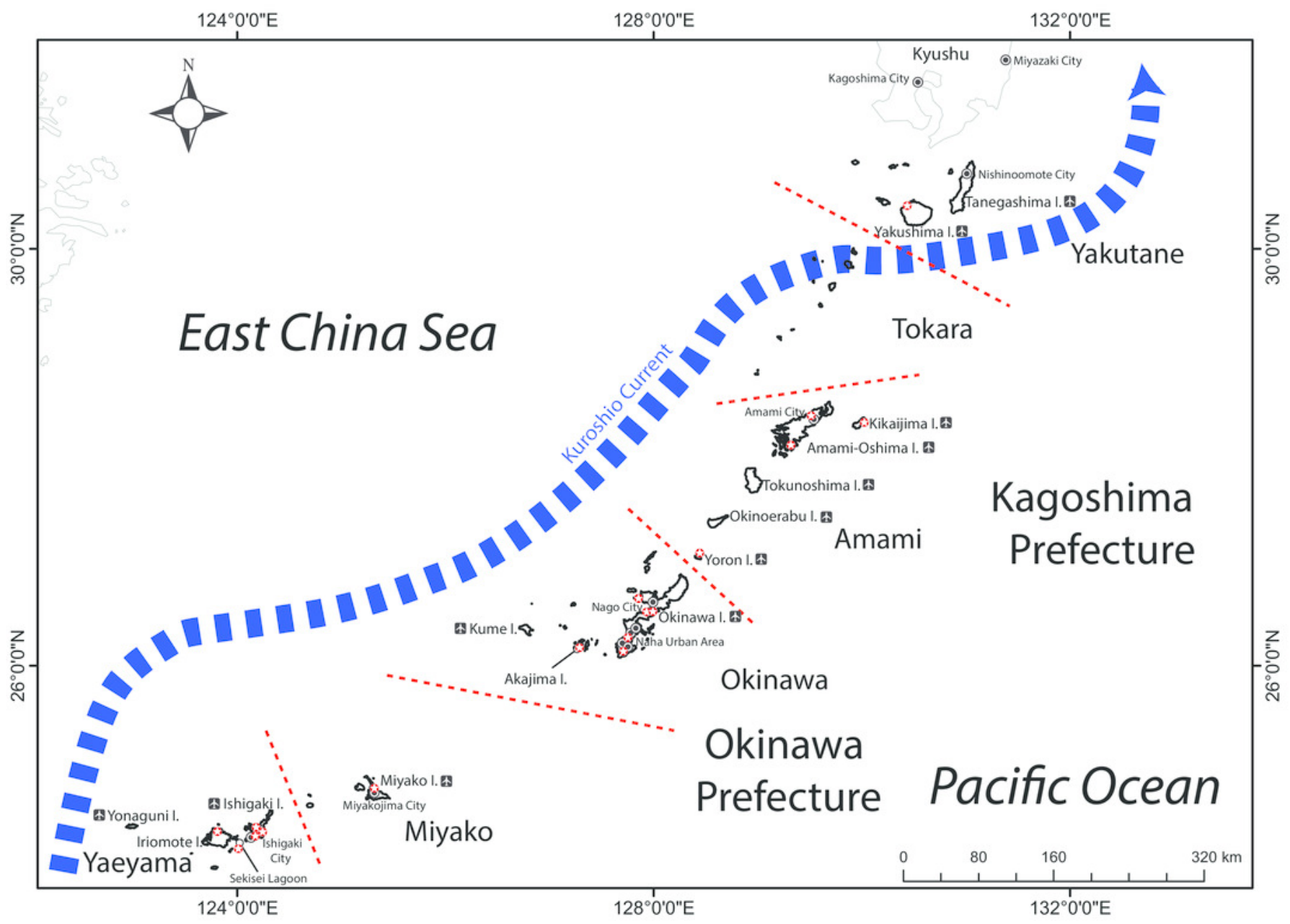


Figure 2

Total number of publications in the Web of Science, and breakdown of these publications by marine taxa.

(a) Total number of publications in the Web of Science (1995-2017) for six different marine taxa (Pisces, Crustacea, Echinodermata, Cnidaria, Porifera, Dinoflagellata) for each subregion in the RYS as well as for undetermined locations and overall total, and (b) the breakdown of these publications by marine taxa. Reference map of the RYS included on the left side.

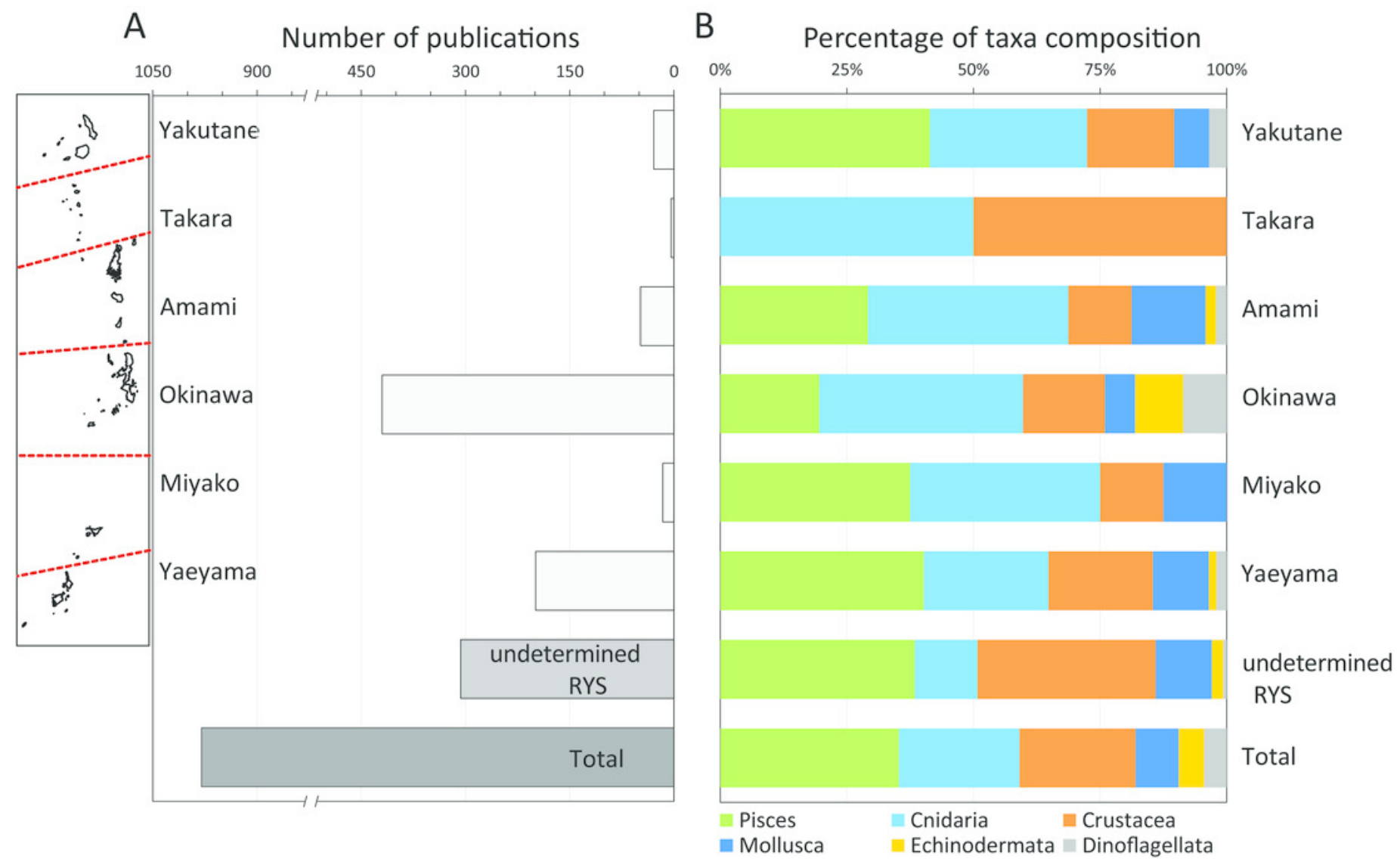

B Percentage of taxa composition 
Figure 3

(a) Numbers of ecological publications per year, and (b) the total number of publications for the Ryukyus (RYS; blue), Red Sea (RES, red), Great Barrier Reef (GBR, grey), and Caribbean (CAR, yellow) from 1995 to 2016 in the Web of Science. 
a

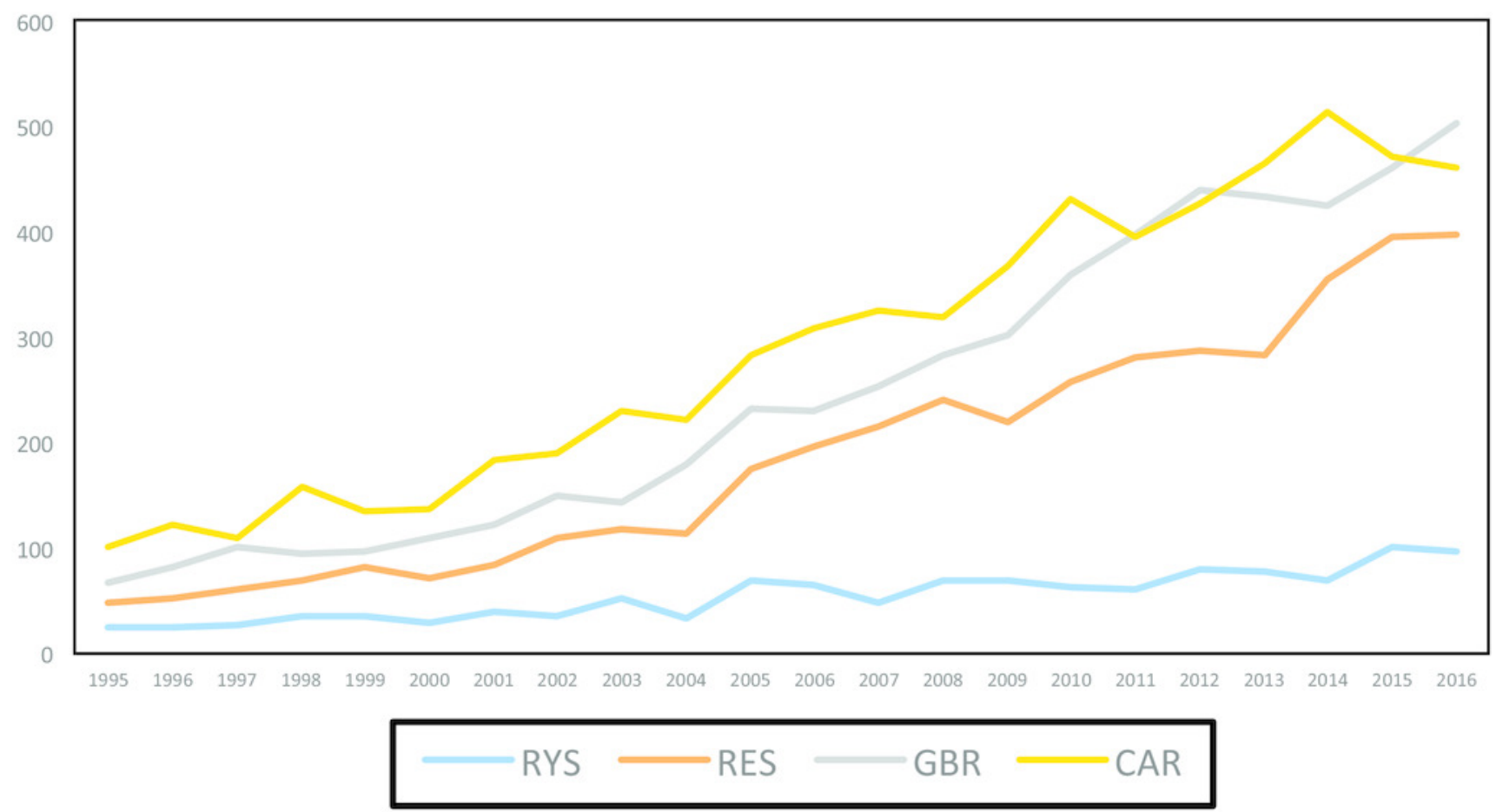

b

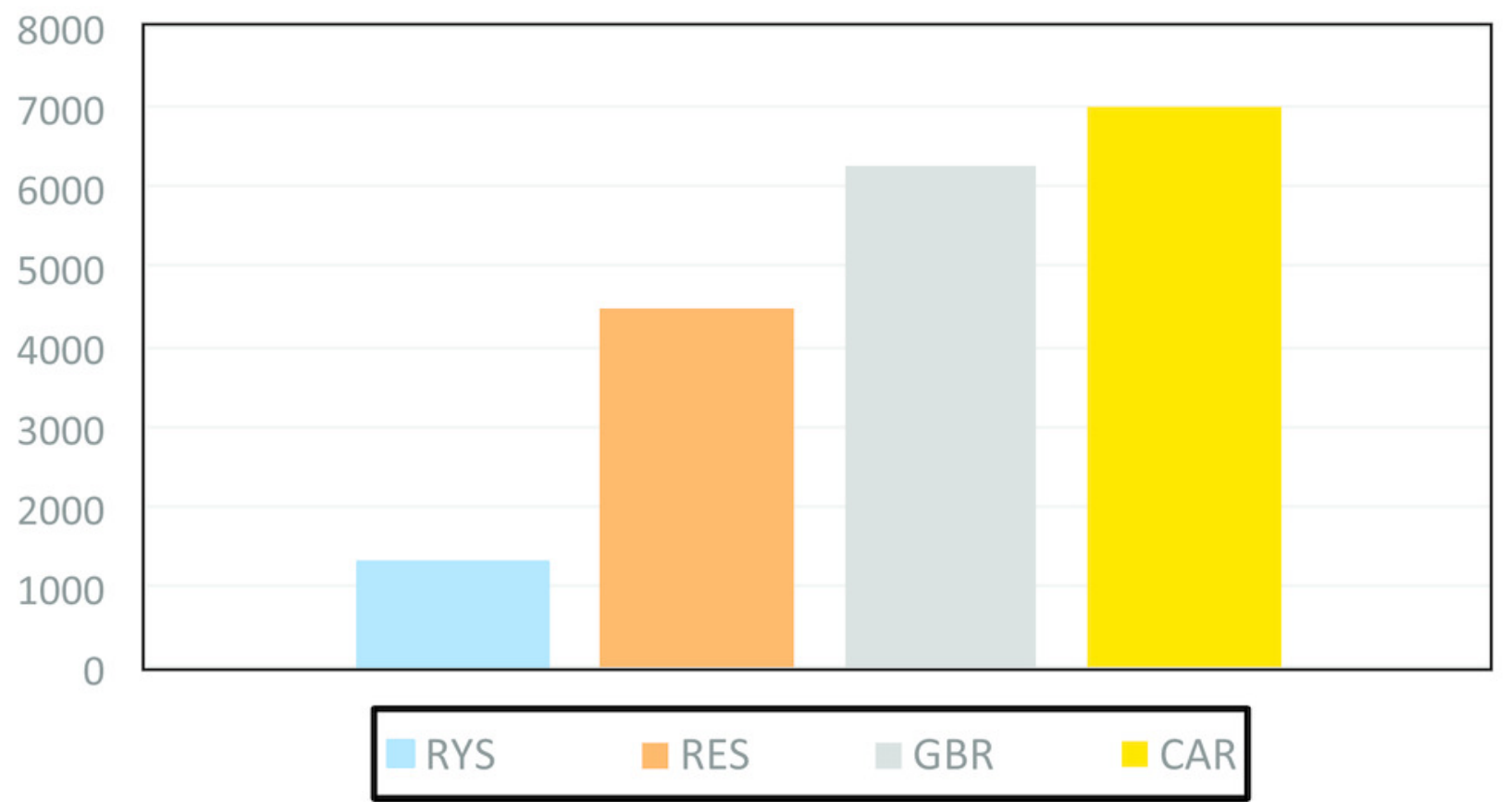




\section{Figure 4}

Number of ecological publications per year for four regions from 1995 to 2016 in the Web of Science; the Ryukyus (RYS; blue), Red Sea (RES, red), Great Barrier Reef (GBR, grey), and Caribbean (CAR, yellow) by topic.

(a) apex predators, (b) herbivory, (c) connectivity, (d) marine protected areas, (e) coral bleaching, (f) Porifera, (g) coral reproduction, and (h) reef-associated bacteria. 
a

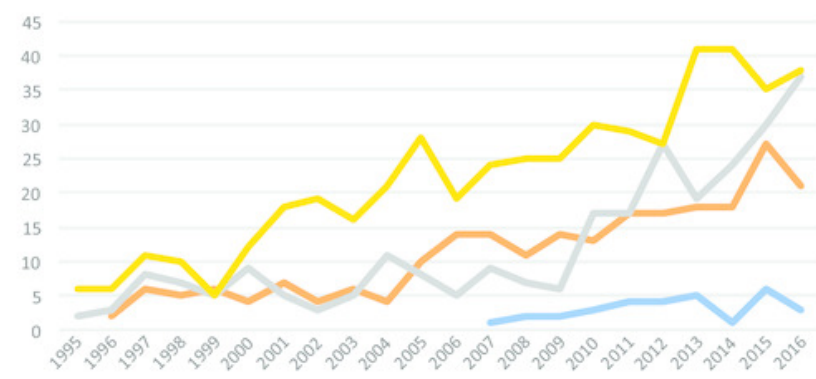

C

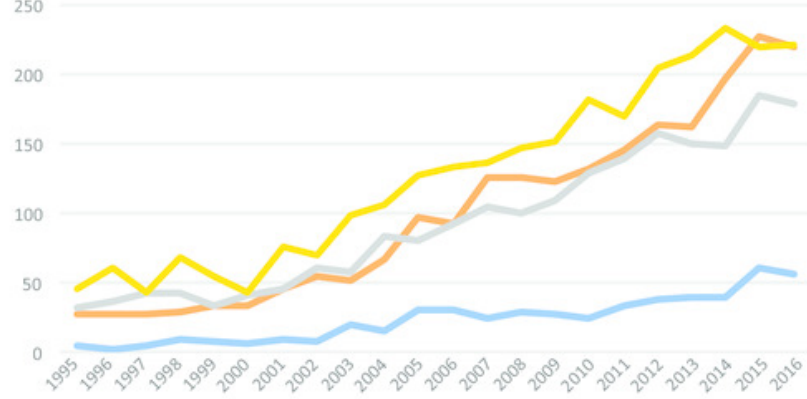

e

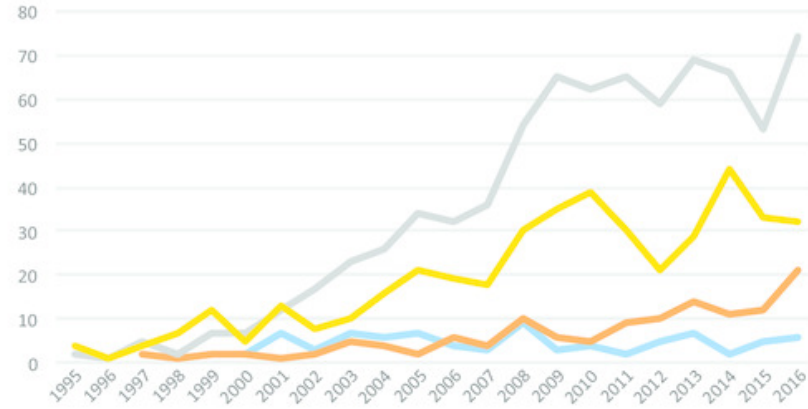

9

35

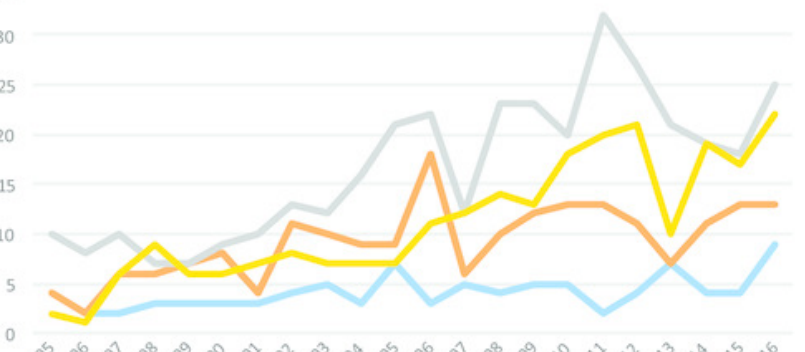

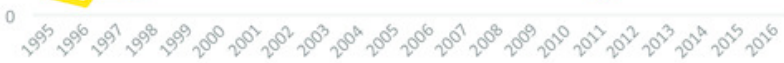

b

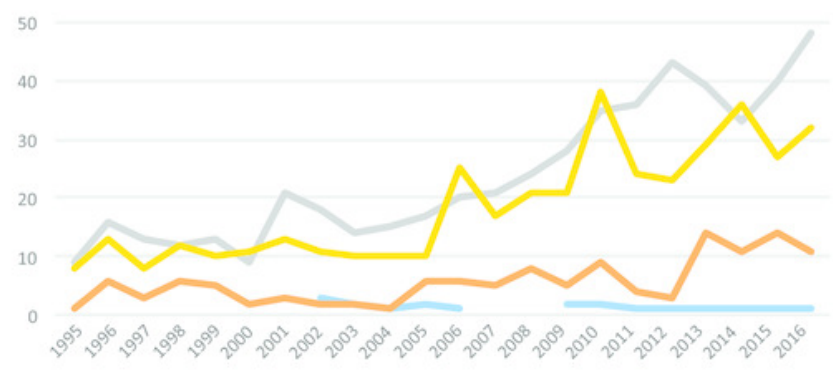

d 80

f

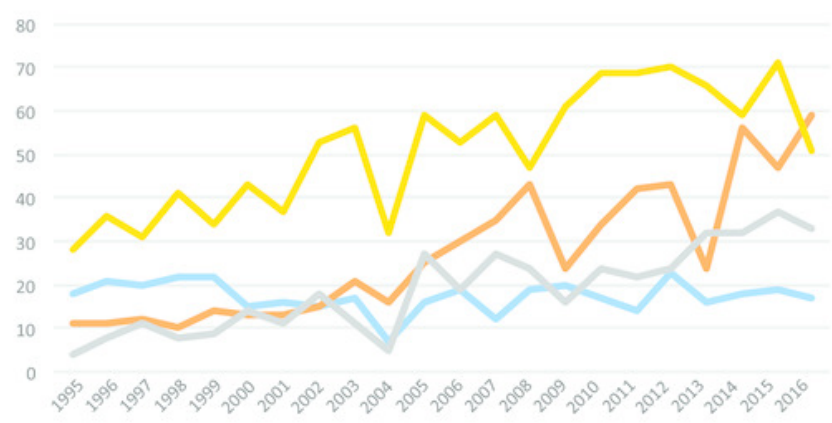

h

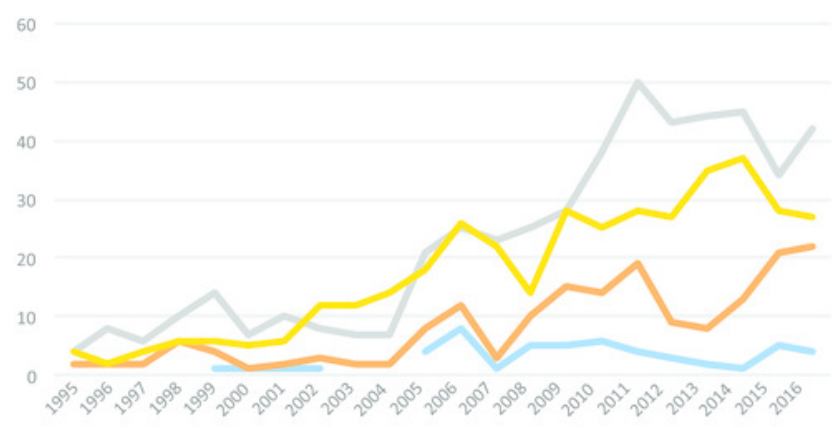

